\title{
Shortening of the oestrous cycle and repeated induction of heat as a method of treatment of repeat breeder cows
}

\section{Summary}

Fifty-four repeat breeder cows were divided into 4 groups (GI to GIV), each one contained 14 cows with the exception of the $1^{\text {st }}$ one which contained 12 cows. The oestrous cycle was shortened in cows of GI and GII by means of injection of $0.5 \mathrm{mg}$ of cloprostenol in GI on day 10 of the cycle and by single intra-uterine infusion of $100-150 \mathrm{ml}$ of Lugol's Iodine from day 3 to 5 of metoestrous in cows of GII. Cows in GIII were infused by Norofloxacin on day 1 to 3 of the $1^{\text {st }}$ and $2^{\text {nd }}$ cycle only. Cows in group IV were left as non-treated affected control and just rested for 3 successive cycles. Insemination was performed at the $3^{\text {rd }}$ induced heat in cows of GI, after 3 cycles ( 2 shortened and one with normal length) in cows of GII and after 3 cycles with normal length in cows of both GIII and GIV. The post-treatment conception rates were determined. There were significant differences $(\mathrm{P}<0.005)$ in the total and first service conception rates between cows in GI and GIII compared with that of those in GIV and GII. Also, there was a significant difference $(\mathrm{P}<0.001)$ for C.R. between cows in GII and those in GIV. From the results of this study, it could be concluded that shortening of oestrous cycle and repeated induction of heats using $\mathrm{PGF}_{2} \alpha$ analogue (cloprostenol) is better than i.u. infusion of antibiotic together with sexual rest for treatment of repeat breeder cows.

$\underline{\text { Key Words: }}$ cows, repeat breeder, heat induction, cloprostenol treatment, shortening of oestrous cycle

\section{Zusammenfassung}

Titel der Arbeit: Verkürzung des Zyklus und wiederholte Brunstinduktion als eine Methode der Behandlung umrindernder Tiere

Insgesamt wurden 54 Kühe nach wiederholtem Umrindern einer von 4 Gruppen zugeordnet. Die Behandlung bestand aus einer dreimaligen Brunstinduktion mit Cloprostenol (G1), einer wiederholten Verabreichung von Lugolscher Lösung im frühen Metöstrus mit nachfolgender Cloprostenolgabe (G2) oder einer intrauterinen Applikation von Norofloxacin über die Dauer von 3 Tagen in zwei aufeinanderfolgenden Zyklen (G3). Die Tiere der 4. Gruppe (G4) blieben unbehandelt und dienten als Kontrolle. Die Tiere von G1 wurden in der dritten Brunst nach Cloprostenol besamt, die der 2. Gruppe nach dreimaliger Infusion von Lugolscher Lösung und zweimaliger Cloprostenolapplikation und die der Gruppen 3 und 4 nach dem Ablauf von drei Zyklen. Die Konzeptionsergebnisse aus Erstbesamung und Gesamtbesamungen waren in den Gruppen 1 und 3 signifikant höher als in den Gruppen 2 und 4. Die wiederholte Behandlung mit Cloprostenol führte zu den vergleichsweise besten Ergebnissen.

Schlüsselwörter: Kühe, Umrinderer, Brunstinduktion, Cloprostenol, Zyklusverkürzung

\section{Introduction}

Intra-uterine infusion of disinfectants as well as antibiotics suppress natural defence mechanisms (FRANK et al., 1983). Also, excessive prolonged intra-uterine infusion of antibiotics in treatment of chronic endometritis is usually followed by establishment of fungi and yeasts in the genital tract of mares (BLUE, 1983; PUGH et al., 1988; POZVARI et al., 1993) and cows (CLINKENBEARD, 1993). In the later decades, 
there is an increasing attention towards recent trends in the treatment of genital infection through:

1. Passive immunization of the uterus by intra-uterine infusion of autogenous serum or plasma in the cow (HUSSAIN and DANIEL, 1991) or in the mare (TROEDSSON et al., 1995) and colostrum in the mare (DEWES, 1979; DEGANNES, 1985).

2. Induction of intra-uterine immune response by active immunization of the uterus (KLUCINSK et al., 1990).

3. Enhancement of the self recovery mechanism of the uterus by induction of oestrus in cycling animals either through $\mathrm{PGF}_{2} \alpha$ injection (ALDMIR and KLILCOGLU, 1988; VUKOVIC et al., 1989; CHOHAN et al., 1991; LAKHDISSI and THIBIER, 1991) or single intra-uterine infusion of Lugol's iodine at day 3 to 5 of the cycle (SEGUIN et al., 1974; KINDHAL et al., 1977). However, repeated induction of oestrus periods has become a valuable alternative to antibiotics to enhance recovery from endometritis (HEMEIDA et al., 1986). Also, the immune response is higher during follicular phase of the oestrous cycle compared with luteal one (AHMED et al., 1993). The aim of this study was to evaluate repeated induction of oestrus with shortening of the cycle length as a method for treatment of repeat breeder cows compared with intra-uterine infusion of antibiotic followed by sexual rest.

Materials and methods

\section{Animals}

A total of 54 repeat breeder Friesian cows were selected so that fulfilling the following criteria proposed by TANABE and CASIDA (1949).

- A minimum of 3 infertile services by fertile semen.

- A minimum of one calving to exclude congenital abnormalities.

- A maximum age of 10 years.

- Normal oestrous cycles with normal intervals between services.

- No palpable abnormalities according the internal genitalia by rectal examination as well as no abnormal genital discharge

These cows were assigned into four groups (GI to GIV), each one contained 14 cows except GI, which contained 12 cows only.

\section{Treatment of animals}

a. Cows in GI and GII:

They were treated for repeated induction of heat together with shortening of the luteal phase as follows:

i. Cows in GI were injected i.m with $500 \mu \mathrm{g}$ cloprostenol on day 10 of one spontaneous and the following two induced cycles to bring the cows into 3 successive heats at 13 days interval within a period of one month. The cows were inseminated at the third induced heat i.e. 29 to 32 days from the beginning of treatment (Fig. 1a).

ii. Cows in GII were infused intra-uterine by $100-150 \mathrm{ml}$ of Lugol's iodine only $1.33 \%$ (SEGUIN et al., 1974) on day 4 of metoestrous of one spontaneous and 
two induced cycles. Afterwards the cows were inseminated at the spontaneous heat occurring 21 days after the second induced heat (Fig. 1b).

\section{b. Cows in GIII:}

They were treated by intra-uterine infusion of $10 \mathrm{cc}$ of Norofloxacin $10 \%$ completed to $50 \mathrm{ml}$ by normal saline every day of the first 3 days of both $1^{\text {st }}$ and $2^{\text {nd }}$ cycle, rested for one cycle and bred at the following heat (i.e. after an average time of $62 \pm 2$ days). The cycle length was normal. Norofloxacin was selected upon culture sensitivity test made for oestrus mucus collected from cows of GIII at the day of oestrus.

\section{c. Cows in GIV:}

They were left as affected non-treated control. They were rested for 3 cycles and bred at the subsequent heat (i.e. after an average interval of 60 days).

Evaluation of the applied regimens of treatment:

The animals were followed to detect post-treatment reproductive parameters. The total conception rate (C.R), the C.R. for $1^{\text {st }}, 2^{\text {nd }}$ and $3^{\text {rd }}$ post-treatment cycles as well as services per conception were determined for different treatment regimens.

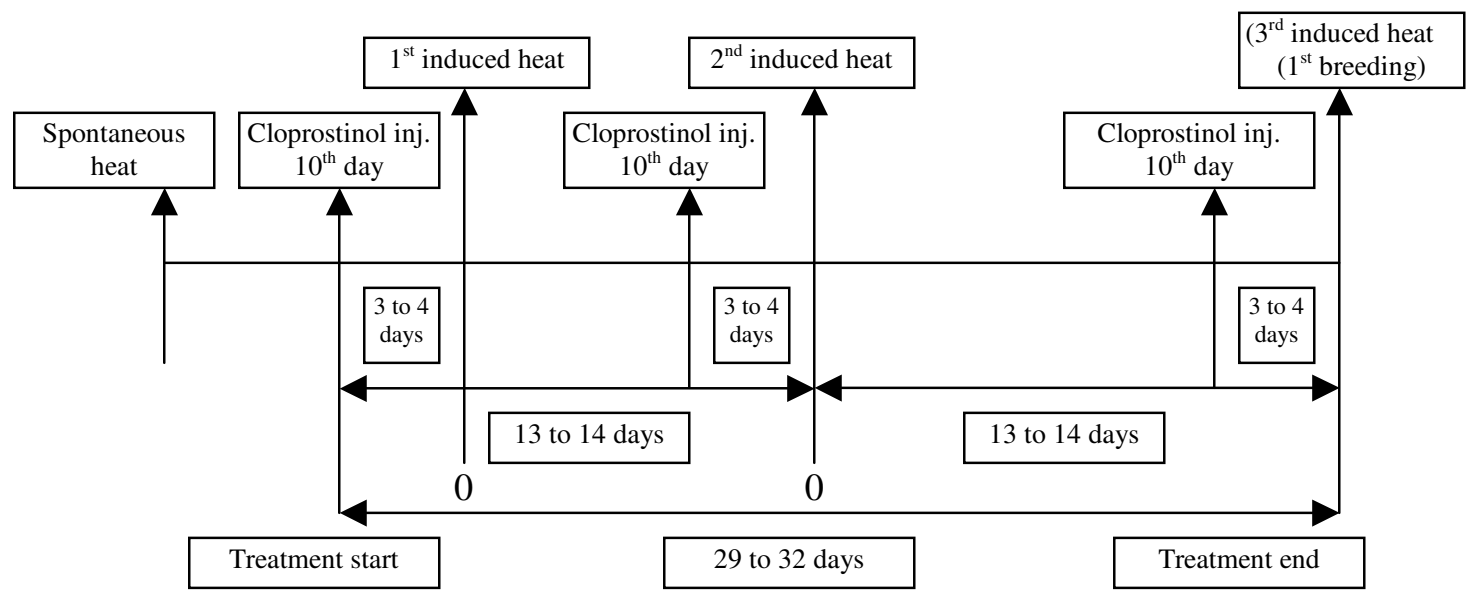

Fig. 1a: Diagrammatic representation of shortening of oestrous cycle length using cloprostenol injection

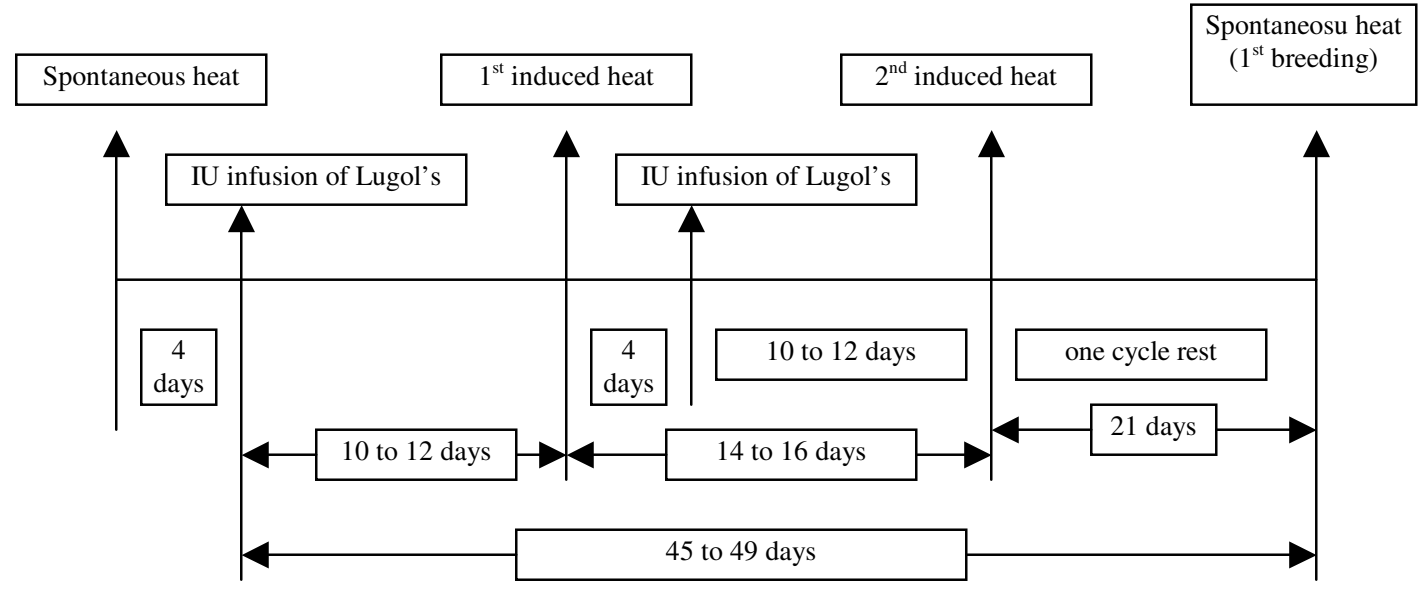

Fig. 1b: Diagrammatic representation of shortening of oestrous cycle using I.U. infusion of Lugol's iodine (1.33\%) 


\section{Results}

As shown in the Table, all cows in GI became pregnant $($ C.R. $=100 \%)$ while $57 \%$, $21.4 \%$ and $7 \%$ of cows in GIII, GIV and GII became pregnant. Also, the first service C.R. was $50 \%, 28.6 \%, 7 \%$ and $0 \%$ in the cows in GI, GIII, GII and GIV respectively. There was a high significant difference $(\mathrm{P}<0.005)$ in the total C.R. between cows in GI and GIII compared with those in GIV and GII. In addition, there was a high significant difference $(\mathrm{P}<0.005)$ in the first service C.R. between cows in GI and GII. Also, there was a significant difference $(\mathrm{P}<0.001)$ in the $1^{\text {st }}$ service C.R. between cows in GII and those in control group GIV. The highest number of services per conception (40) was recorded in cows of GII. Also, the services per conception were significantly higher (14) for cows in GVI compared to those for cows in GIII and GI (3.75 and 1.66 rsp.; Tab.).

Table

The conception rate (C.R.) and services per conception (s/c) in cows of different groups

\begin{tabular}{|c|c|c|c|c|c|c|c|c|}
\hline Reproductive parameter & & Concepti & rate $(\%$ & & & ices per & nceptio & \\
\hline Group & $\begin{array}{c}1^{\text {st }} \\
\text { insem. }\end{array}$ & $\begin{array}{l}2^{\text {nd }} \\
\text { insem. }\end{array}$ & $\begin{array}{l}3^{\text {rd }} \\
\text { insem. }\end{array}$ & Total & $\begin{array}{c}1^{\text {st }} \\
\text { insem. }\end{array}$ & $\begin{array}{c}2^{\text {nd }} \\
\text { insem. }\end{array}$ & $\begin{array}{l}3^{\text {rd }} \\
\text { insem. }\end{array}$ & Total \\
\hline $\begin{array}{l}\text { GI (cloprostenol) } \\
\mathrm{n}=12\end{array}$ & $\begin{array}{c}\text { a. } * * * \\
50\end{array}$ & 83.33 & 100 & $\begin{array}{c}\text { a. } * * * \\
100\end{array}$ & 2 & 1.8 & 1.66 & 1.66 \\
\hline $\begin{array}{l}\text { GII (Lugol's) } \\
\mathrm{n}=14\end{array}$ & $\begin{array}{c}\text { b. }{ }^{* *} \\
7\end{array}$ & 7 & 7 & 7 & 14 & 27 & 40 & 40 \\
\hline $\begin{array}{l}\text { GIII (Norofloxacin) } \\
\mathrm{n}=14\end{array}$ & $\begin{array}{l}\text { a. } * * * \\
28.6\end{array}$ & 57 & 57 & $\begin{array}{c}\text { a. } * * * \\
57\end{array}$ & 3.5 & 3 & 3.75 & 3.75 \\
\hline $\begin{array}{l}\text { GIV (control) } \\
\text { affected non treated } n=14\end{array}$ & 0 & 0 & 21.4 & 21.4 & 0 & 0 & 14 & 14 \\
\hline
\end{tabular}

\section{Discussion}

The first service conception rate is a valuable tool for evaluation of fertility. A goal of $60-70 \%$ first service conception rate is a goal of well-managed herds. The overall average for progressive dairy herds is $50 \%$ or less (SHULTZ, 1987). The results of the present study show that the first service conception rate was $50 \%, 26.8 \%, 7 \%$ and $0 \%$ for cows in GI, GIII, GII and GIV respectively. The first service C.R. (50\%) in cows of GI coincides with that recorded by (SHULTZ, 1987) and being lower than that $(62.2 \%)$ recorded by (CHOHAN et al., 1991) for $1^{\text {st }}$ service C.R. in buffaloes after injection of cloprostenol. Both the high total C.R. $100 \%$ and first service C.R. $50 \%$ as well as the normal number of services per conception for cows in GI reflect the rapid self-recovery of their genitalia. This coincides with HEMEIDA et al. (1986) who reported that two $\mathrm{PGF}_{2} \alpha$ treatments with 10-14 days in-between appeared to hasten recovery and reduce interval from calving to breeding. Also, VUKOVIC et al. (1989) reported self-cleansing of the uterus after application of $\mathrm{PGF}_{2} \alpha$. This may be attributed to the fact that repeated induction of heat acts in two fold, the first is to increase the resistance of the uterus during heat periods as a result of action of recurrent periods of high estrogen levels (RAWSON et al., 1953). The $2^{\text {nd }}$ fold is shortening of the luteal phase of the oestrous cycle during which the animal is being susceptible to infection (RAWSON et al., 1953; ANDERSON et al., 1985; LeBLANC et al., 1988; AL EKNAH and NOAKES, 1989). Moreover, the number of polymorphonuclear leucocytes (PMNS) constitutes $70 \%$ of cells present in the uterine lumen at the $2^{\text {nd }}$ day after ovulation (KLUCINSKI, 1990) and only 3\% in the remaining phases of the 
oestrous cycle (TARGOWSKI, 1984; KLUCINSKI et al., 1990). The total conception rate $(57 \%)$ and first service C.R. (28.6\%) for cows in GIII were significantly lower than C.R. for cows in GI. This may be attributed to incomplete clearance of infection which may be attributed to the fact that intra-uterine infusion of antibiotics decrease natural defence mechanism (FRANK et al., 1983) as well as prolonged luteal phases compared to cows in GI during which the animal is susceptible to reinfection after treatment (RAWSON et al., 1953; ANDERSON et al., 1985; LeBLANC et al., 1988). Also, the use of antibiotics may predispose for another types of infection as fungal infection (BLUE, 1983; CLINKENBEARD, 1993; POZVARI et al., 1993 ). Regarding the $1^{\text {st }}$ service C.R. in case of cows of GII, it was significantly lower than both GI and GIII. This may be attributed to the degenerative changes, which may interfere with implantation. These changes are produced by intra-uterine infusion of Lugol's Iodine. This is coinciding with (SEGUIN et al., 1974) who stated that i.u. infusion of Lugol's $(1.33 \%)$ resulted in necrotizing endometritis, which occurred as early as 24 hours. Also, SCHNYDER et al. (1990) reported that i.u infusion of Lugol's Iodine resulted in high degree of degenerative and inflammatory changes within 24 hours, which require 10-15 days for regeneration. It could be concluded that shortening of oestrous cycle and repeated induction of heat using $\mathrm{PGF}_{2} \alpha$ analogue (Cloprostenol) is better than i.u infusion of antibiotic together with sexual rest for treatment of repeat breeder cows.

\section{References}

AHMED, W.M.; NADA, A.R.; SHALABY, S.T.:

Uterine humoral and cellular immune response in some cases of genital disorders in buffaloes. Rep. Dom. Anim., 28 (1993), 298-301

ALDMIR N.; KLILCOGLU, C.:

Treatment of chronic endometritis in cattle with $\mathrm{PGF}_{2} \alpha$ analogue (Luprostiol and dinprost trometamol), veterinary Fakultesi Dergisi, Uludag Universitesi (1986-1987 Publ. 1988) 5-6 (1-3) (1988), 57-60

AL-EKNAH, M.H.; NOAKES, D.E.:

Uterine activity in cows during the estrous cycle, after ovarectomy and following exogenous estradiol and progesterone. British Vet. J., 145 (1989), 328-335

ANDERSON, K.L.; HEMEIDA, N.A.; FRANK, A.; WHITEMORE, H.L.; GUSTAFSSON, B.K.:

Collection and phagocytic activity of the uterine neutrophilic leukocytes. Theriogenology, 24 (1985), 305-314

BLUE, M.G.:

Mycotic invasion of mare's uterus. Vet. Rec., 113 (1983), 131-132

CHOHAN, K.R.; CHADHRY, M.A.; CHAUDHRY, R.A.:

Treatment of endometritis using prostaglandin $\mathrm{F}_{2} \alpha$ in Nilli-Ravi buffaloes. Buffalo Bulletin, 10 (1991) 1, 14-17

CLINKENBEARD, K.D.:

Mastitis, metritis, traumatic reticuloperitonitis and suspected fungal ruminits in a cow. JAVMA, 203 (1993) 10, 1404-1410

DEGANNES, V.G.:

Uterine infusion of colostrum in barren mares. Modern Vet. Practice, 66 (1985) 2, A2-A4

DEWES, H.F.:

Preliminary observations on the use of colostrum as an uterine infusion in thoroughbred mares. N.Z. Vet. J., 28 (1979), 7-8

FRANK, T.; ANDERSON, K.L.; SMITH, A.R; WHITEMORE, H.L.; GUSTAFSSON, B.: Phagocytosis in uterus, A Review. Theriogenology, 20 (1983), 103

HEMEIDA, N.A.; GUSTAFSSON, B.; BORJE, K.; WHITMORE, H.L.:

Therapy of uterine infections: Alternatives to antibiotics. Current Therapy of Theriogenology, 2 (1987), 45-47

HUSSAIN, A.M.; DANIEL, R.C.W.:

Bovine endometritis: Current and future alternative therapy. J. Vet. Med. Series A., 38 (1991) 9, 641-651 
KINDHAL, H.; GRANSTROM, E.; EDQUIST, L.E.; GUSTAFSSON, B.; STABENFELD, G.H.:

Progesterone \& 15-keto 13, 14 dihydro prostaglandin $\mathrm{F}_{2} \alpha$ levels in peripheral circulation after intrauterine infusion in cows. Acta. Vet. Scand., 18 (1977), 274

KLUCINSK, W.; TARGOWSKI, S.E.; MIERINK-DEGORESKA, E.; WINNICKA, A.:

The phagocytic activity of the polymorphonuclear leukocytes isolated from normally uterus and that with experimentally induced inflammation in cows. J. Vet. Med. A., 37 (1990) 50, 512

LAKHDISSI, C.H.; THIBIER, M.:

Epidemiological and clinical study of post puerperium endometritis in dairy cattle. Recueil de Medecine Veterinaire special Reproduction de Ruminants, Mares-Avril (1991), 350-358

LeBLANC, M.M.; HANSEN, P.J.; BUHI, W.:

Uterine protein secretion in postpartum and cycle mares, Theriogenology, 29 (1988), 1003-1016

OLD, D.; COOPER, T.; THNFT, F.A.:

Effect of days open on economic aspect of current lactation. J. Dairy Sci., 62 (1979), 1167

POZVARI, M.; SCHERBARTH R.; HEILKENBRINKER, T.; FERKING, H.; LEHMACHER, W.:

Yeast in cervical swabs from mares with reference to case history and the results of clinical examination. Praktischer Tierarzt, 74 (1983) 9, 777-781

PUGH, D.; MARTIN, M.T.; SHULL W.; BOWEN, M.

Endometrial condidasis of five mares J. Eguine Vet. Sci., 6 (1986), 40-43

RAWSON, L.E.; LAMNING, G.E.; FRY, R.M.:

The relationship between ovarian hormones and uterine infection. Vet. Rec., 65 (1953) 22, 335-341

SCHNYDER, D.; KOPFER, U.; ZWAHLEN, R.:

Endometrial histology after infusion of various drugs into the uterus of cows. Schweizer Archiv für Tierheilkunde, 132 (1990) 7, 353-364

SCHULTZ, H.R.:

Objective evaluation of reproductive herd performance society for Theriogenology. Cow Manual, (1987), 157-161

SEGUIN, B.E.; MORROW, D.A.; LOUS, T.M.:

Luteolysis, Luteostasis and effect of $\mathrm{PGF}_{2} \alpha$ in cows after endometrial irritation. Am. J. Vet. Res., (1974), $35-57$

TANABE, T.Y.; CASIDA, L.E.:

The nature of reproductive failures in cows of low fertility. J. Dairy Sci., 32 (1949), 237-246

TROEDSSON, M.H.T.; SCOTT, M.A.; LIU, I.K.M.:

Comparative treatment of mares susceptible to chronic uterine infection. Am. J. Vet. Res., 56 (1995) 4, 468-472

TARGOWSKI, S.P.:

Immunologically induced uterine inflammation, proceeding of $10^{\text {th }}$ international congress in animal reproduction and artificial insemination. Urabana, (1984), 473

VUKOVIC, D.; JASKIC, Z.; ERSKIBILJIC, M.; PETRUJKIC, T. MARKOVIC, B.; RAKIN, V.:

Contribution to the use of $\mathrm{PGF}_{2} \alpha$ and analogue for the therapy of chronic endometritis. Vet. Glasnik, $\mathbf{4 3}$ (1989) 5, 461-465

Received: 2000-05-23

Accepted: 2001-08-23

Authors addresses

Dr. ADEL A. RAMOUN

Department of Theriogenology, Faculty of Veterinary Medicine, Tanta University (Kafr El-Sheikh Branch), Kafr El-Sheikh, Egypt.

Dr. ABD EL-GAOAD KADOOM, Prof. Dr. FIKRY M. FOUAD

Animal Production Research Institute, Shakha, Kafr El-Sheikh, Egypt. 